\title{
PENGARUH BROKOLI (Brassica oleracea var. Italica) DALAM MENGHAMBAT OKSIDASI LEMAK PADA NUGGET TEMPE KEDELAI SELAMA PENYIMPANAN
}

\author{
Effect of Broccoli (Brassica oleracea var. Italica) In Inhibiting Fat Oxidation of Soy \\ Tempe Nugget During Storage
}

\author{
Ezra A. Emeline ${ }^{*}$, Mercy I. R. Taroreh², Thelma D. J. Tuju ${ }^{2}$ \\ ${ }^{1}$ Mahasiswa Program Studi Teknologi Pangan \\ ${ }^{2}$ Dosen Program Studi Teknologi Pangan \\ Jurusan Teknologi Pertanian, Fakultas Pertanian, Universitas Sam Ratulangi Manado \\ Jl. Kampus UNSRAT Manado 95115
}

*Email: ezraemeline@gmail.com

\begin{abstract}
The purpose of this research is to determine the influence of broccoli comparison in inhibiting fat oxidation of soybean tempe nugget before and after 30 days of storage and to evaluate the acceptance rate of soybean tempe nugget with broccoli comparison before and after of 30 days storage. This study consisted of 4 comparative treatments of broccoli and soybean tempe, which is $0 \%$ broccoli and $100 \%$ tempe in treatment $\mathrm{A}$, $10 \%$ broccoli and $90 \%$ tempe in treatment B, 20\% broccoli and $80 \%$ tempe in treatment $\mathrm{C}$, and $30 \%$ broccoli and $70 \%$ tempe in the treatment D. Soybean tempe nugget is tested on 0 days and 30 days storage. The results showed the influence of the broccoli comparison in inhibiting the oxidation of tempe nuggets. Tempe nuggets with broccoli comparison is best reviewed from the levels of free fatty acids (ALB), peroxide value, and the value of thiobarbituric acid (TBA) is treatment $\mathrm{B}$. The acceptance rate of soybean tempe nugget on color, aroma, taste, and texture is in the likes category. Where the most preferred soybean tempe nugget is treatment B with a concentration of broccoli as much as $10 \%$.
\end{abstract}

Keywords : Nugget, Tempe, Broccoli, Oxidation

\section{PENDAHULUAN}

Tempe kedelai adalah salah satu makanan tradisional khas Indonesia yang terbuat dari biji kedelai yang diproses dengan cara fermentasi. Tempe kedelai mempunyai keunggulan yaitu kadar protein yang tinggi. Tempe mempunyai kandungan gizi protein yang merupakan zat gizi potensial bagi penduduk Indonesia karena nilai gizinya sebanding dengan sumber protein hewani seperti daging sapi, susu sapi dan telur ayam (Koswara, 1992 dalam Mulyani, 2013). Namun tempe kedelai dalam penyimpanannya masih mempunyai kendala yaitu umur simpan yang singkat dan mudah rusak sehingga salah satu cara untuk mempertahankan umur simpan tempe adalah dengan mengolahnya menjadi nugget. Nugget merupakan salah satu produk pangan cepat saji yang saat ini dikenal baik oleh masyarakat. Nugget seperti halnya sosis, burger, pizza, hotdog 
dan corned telah menjadi salah satu pilihan masyarakat sebagai produk pangan yang praktis. Nugget biasanya terbuat dari daging-dagingan seperti ayam, sapi, atau ikan, tetapi sekarang sudah banyak penelitian yang menyatakan bahwa nugget dapat dibuat dari bahan nabati seperti kacang merah, jamur merang, jamur tiram, dan tempe (Amaliyah, 2009; Alfiana, 2014).

Nugget merupakan produk yang harus digoreng terlebih dahulu sebelum disantap. Proses penggorengan dapat menyebabkan reaksi hidrolisis dan oksidasi lemak (Zhang, dkk, 2012). Hidrolisis lemak dapat menghasilkan asam lemak bebas yang menyebabkan ketengikan begitu pula dengan oksidasi terhadap asam lemak tidak jenuh yang menghasilkan peroksida serta turunannya seperti aldehida dan keton (Taroreh, 1998). Ketengikan biasanya menjadi tolak ukur mutu pangan.

Brokoli (Brassica olaracea var. Italica) merupakan salah satu famili dari Brassicaceae yang mengandung fitokimia seperti senyawa fenolik, serat dan senyawa antioksidan seperti vitamin $\mathrm{C}$ dan E serta mineral $(\mathrm{Ca}, \mathrm{Mg}, \mathrm{Se}$,dan $\mathrm{K})$ (Moreno, dkk, 2006). Brokoli banyak dikonsumsi dalam bentuk olahan atau dikonsumsi dalam bentuk mentah atau segar. Brokoli merupakan sayuran yang telah diteliti mempunyai kandungan antioksidan (Yuliani, 2012).

Antioksidan merupakan komponen yang dapat menunda, memperlambat, atau mencegah kerusakan pada bahan makanan akibat oksidasi. Antioksidan tidak dapat memperbaiki kembali bahan makanan yang telah mengalami oksidasi, tetapi hanya menghambat reaksi oksidasi (Rauf, 2015). Berdasarkan penjelasan diatas maka dilakukan penelitian tentang pengaruh brokoli dalam menghambat oksidasi lemak pada nugget tempe kedelai selama penyimpanan.

\section{METODE PENELITIAN}

\section{Tempat dan Waktu}

Penelitian ini sudah dilaksanakan di Laboratorium Ilmu Pangan, Jurusan Teknologi Pertanian, Fakultas Pertanian, dan Laboratorium Farmasi, Fakultas Matematika dan Ilmu Pengetahuan Alam, Universitas Sam Ratulangi, Manado, Sulawesi Utara dengan jangka waktu 2 bulan (Februari sampai Maret 2019).

\section{Bahan dan Alat}

Bahan yang digunakan dalam penelitian ini adalah tempe, brokoli, tepung tapioka, air, bawang putih, bawang merah, merica, garam, gula, telur, tepung roti, margarin, dan minyak goreng serta bahan-bahan kimia untuk analisis yaitu aquades, phenolphthelin (PP), $\mathrm{NaOH}$, alkohol netral, pati, $\mathrm{Na}_{2} \mathrm{~S}_{2} \mathrm{O}_{3}$ (natrium thiosulfat), KI, kloroform, asam asetat glasial, $\mathrm{HCl}$, dan TBA.

Alat yang digunakan dalam penelitian ini adalah blender, food processor, freezer, dan alat-alat untuk analisis yaitu tabung reaksi, erlenmeyer, gelas ukur, batang pengaduk, mikropipet dan tip, timbangan analitik, rak tabung reaksi, buret, dan spektrofotometer UVVis.

\section{Rancangan Penelitian}

Penelitian menggunakan

Rancangan Acak Lengkap (RAL). Setiap perlakuan diulang sebanyak 3 kali. Sehingga diperoleh 12 unit percobaan (Tabel 1.) kemudian dianalisis dengan menggunakan metode analisis sidik ragam (Analysis of Variance/ANOVA).

Tabel 1. Perlakuan Komposisi Tempe dan Brokoli

\begin{tabular}{cc}
\hline Perlakuan & $\begin{array}{c}\text { Perbandingan } \\
\text { (Tempe (\%) : Brokoli (\%)) }\end{array}$ \\
\hline A & $100: 0$ \\
B & $90: 10$ \\
C & $80: 20$ \\
D & $70: 30$ \\
\hline
\end{tabular}


Selanjutnya untuk menentukan nilai yang berpengaruh maupun yang tidak dengan uji BNT (Beda Nyata Terkecil).

\section{Prosedur Penelitian}

Penyiapan Brokoli (Luthfi, dkk, 2017) dan Tempe (Rohaya, dkk, 2013)

Penyiapan brokoli dilakukan penyortiran terlebih dahulu. Brokoli dilepaskan dari tangkainya, kemudian dicuci dengan menggunakan air bersih yang mengalir lalu diblansir. Brokoli ditimbang dan dihancurkan menggunakan blender. Selanjutnya brokoli ditambahkan air dengan perbandingan $(2: 1=$ Brokoli : Air) hingga lembut. Sedangkan untuk penyiapan tempe meliputi pencucian tempe kemudian dipotong $1 \mathrm{~cm} \mathrm{x} 1 \mathrm{~cm}$ dan ditimbang untuk setiap unit percobaan kemudian dikukus selama 10 menit untuk menginaktifkan enzim pada tempe sehingga tidak berbau tengik. Lalu tempe dihancurkan dengan menggunakan food processor selama 10 - 15 detik.

\section{Pembuatan Nugget Tempe (Rohaya, dkk, 2013 yang dimodifikasi)}

Tempe yang telah dikukus kemudian dihancurkan dengan food processor dan dilakukan pencampuran dengan brokoli sesuai perbandingan yang ditetapkan. Selanjutnya dilakukan pencampuran yaitu sebanyak $40 \%$ bahan (tempe dan brokoli), tepung tapioka 20\%, dicampurkan semua bumbu halus (berdasarkan berat tempe yang digunakan) sesuai dengan persentase berat bahan yang telah ditentukan (bawang merah $12 \%$, bawang putih $8 \%$, kuning telur 9\%, merica bubuk $0,5 \%$, gula $0,5 \%$, garam 3 $\%$, air $7 \%$ ).

Adonan dicetak pada loyang (yang telah dioles margarin) dengan ketebalan 1 $\mathrm{cm}$ dan dipadatkan dengan cara ditekan agar teksturnya kompak, kemudian donan dikukus selama 20 menit. Adonan yang telah dikukus didinginkan selama 5 menit kemudian dipotong dengan ukuran panjang $5 \mathrm{~cm}$ dan lebar $1 \mathrm{~cm}$ dan dilakukan pelapisan dengan batter (pencelupan ke dalam putih telur dari telur ayam yang telah dikocok) dan breader (pelapisan dengan menggunakan tepung roti). (Pembuatan nugget ini tidak didahului oleh penggorengan setengah matang). Nugget dibekukan di dalam freezer pada suhu $-5^{\circ} \mathrm{C}$. Nugget yang telah dibekukan harus di-thawing terlebih dahulu sebelum digoreng, agar kristal es yang ada di dalam nugget cepat mencair, sehingga ketika nugget digoreng, nugget tersebut cepat matang.

\section{Variabel Pengamatan}

- Uji kadar asam lemak bebas

- Uji bilangan peroksida

- Uji Thiobarbituric Acid/TBA

- Uji organoleptik tingkat penerimaan terhadap warna, aroma, rasa, dan tekstur

\section{Prosedur Analisis \\ Uji Asam Lemak Bebas (Sudarmadji, dkk, 1984)}

Timbang sebanyak 5 gram contoh dalam erlenmeyer. Tambahkan $50 \mathrm{ml}$ alkohol netral yang panas dan $2 \mathrm{ml}$ indikator phenolphthalein (PP). Titrasilah dengan larutan $0,1 \mathrm{~N} \mathrm{NaOH}$ sampai warna merah jambu tercapai dan tidak hilang selama 30 detik. Persen asam lemak bebas dinyatakan sebagai palmitat pada minyak kelapa sawit. Asam lemak bebas dinyatakan sebagai \% FFA. Perhitungan anga FFA sesuai rumus berikut.

$\% \mathrm{FFA}=\frac{m l \mathrm{NaOH} x \mathrm{~N} x \mathrm{BM} \text { asamlemak }}{\text { berat contoh } x 1000} \times 100$

\section{Uji Bilangan Peroksida (Sudarmadji, dkk, 1984)}

Timbang 5 gram contoh dalam 250 $\mathrm{ml}$ erlenmeyer bertutup dan tambahkan 30 $\mathrm{ml}$ larutan asam asetat-khloroform (3:2). Goyangkan larutan sampai bahan terlarut semua. Tambahkan $0,5 \mathrm{ml}$ larutan jenuh KI. Diamkan selama 1 menit dengan 
kadang kala digoyang kemudian tambahkan $30 \mathrm{ml}$ aquades. Titrasilah dengan 0,1 $\mathrm{N} \quad \mathrm{Na}_{2} \mathrm{~S}_{2} \mathrm{O}_{3}$ sampai warna kuning hampir hilang. Tambahkan $0,5 \mathrm{ml}$ larutan pati $1 \%$. Lanjutkan titrasi sampai warna biru hilang. Angka peroksida dinyatakan dalam mili-equivalen dari peroksida dalam setiap kg contoh.

Angka peroksida $=\frac{m l N a_{2} S_{2} O_{\mathbb{3}} \times N \text { thio } x 1000}{\text { berat } \operatorname{contoh}(g)}$

Uji Thiobarbituric Acid/TBA (Tarladgis, dkk, 1960 dalam Sudarmadji, dkk, 1984)

Timbang bahan sebanyak kira-kira 3 gram dengan teliti, masukkan ke dalam Waring blender, tambahkan $50 \mathrm{ml}$ aquades dan hancurkan selama 2 menit. Pindahkan secara kuantitatif ke dalam labu destilasi $1000 \mathrm{ml}$ sambil dicuci dengan $48,5 \mathrm{ml}$ aquades. Tambahkan \pm $1,5 \mathrm{ml}$ kira-kira $4 \mathrm{~N} \mathrm{HCl}(1$ bagian $\mathrm{HCl}$ pekat dalam 2 bagian air) sampai $\mathrm{pH}$ menjadi 1,5. Tambahkan batu didih dan bahan pencegah buih (antifoam) sedikit dan pasanglah labu distilasi pada alat distilasi. Distilasi dijalankan dengan pemanasan setinggi mungkin sehingga diperoleh distilat sebanyak $50 \mathrm{ml}$ selama pemanasan 10 menit. Aduklah distilat yang diperoleh, saring dan pindahkan $5 \mathrm{ml}$ ke dalam erlenmeyer $50 \mathrm{ml}$ yang bertutup dan tambahkan $5 \mathrm{ml}$ reagen TBA. Reagen TBA: larutan 0,02 M thiobarbituric-acid dalam $90 \%$ asam asetat glasial. Pelarutan dipercepat dengan pemanasan di atas penangas air. Campurlah larutan baik-baik dan masukkan erlenmeyer tertutup dalam air mendidih selama 35 menit. Setelah didinginkan dengan air pendingin, bacalah Optical Density dengan spektrofotometer pada panjang gelombang $528 \mathrm{~nm}$ dengan larutan blanko sebagai titik nol. Angka TBA dihitung dan dinyatakan dalam $\mathrm{mg}$ malonaldehid/kg sampel. Perhitungan angka TBA sesuai rumus sebagai berikut.

Angka TBA $=\frac{3 x A 528 x 7,8}{\text { Berat Sampel }(g)}$
Keterangan:

A528 = Absorbansi pada $528 \mathrm{~nm}$

$7,8=$ Bilangan $\mathrm{TBA} \quad \mathrm{mg}$ malonaldehid/kg sampel

$3=$ Bilangan iod merupakan derajat ketidakjenuhan minyak/lemak

\section{Uji Organoleptik}

Produk disajikan kepada panelis sesuai banyaknya perlakuan. Uji organoleptik yang dilakukan adalah uji tingkat kesukaan atau uji hedonik. Skala hedonik yang digunakan adalah skala 1 sampai 5. Uji organoleptik yang diukur adalah warna, aroma, rasa, dan tekstur. Uji organoleptik dari nugget tempe dan brokoli dipilih mahasiswa sebanyak 25 orang untuk dijadikan panelis dengan 5 skala hedonik (sangat tidak suka - sangat suka). Sampel disajikan saat nugget sudah digoreng sampai matang sesuai perlakuan yang ada.

\section{HASIL DAN PEMBAHASAN}

\section{Kadar Asam Lemak Bebas (ALB)}

Data kadar ALB nugget tempe kedelai dengan perbandingan brokoli pada berbagai konsentrasi ditunjukkan pada Gambar 1. Hasil penelitian menunjukkan bahwa kadar ALB perlakuan perbandingan brokoli dalam nugget tempe pada penyimpanan 0 hari berkisar antara $2,44 \%$ sampai $3,15 \%$ dan pada penyimpanan 30 hari kadar berkisar antara $2,73 \%$ sampai $3,53 \%$. Berdasarkan hasil analisis sidik ragam 5\%, perlakuan perbandingan brokoli dalam nugget tempe kedelai memberikan pengaruh nyata terhadap kadar ALB yang berarti terdapat perbedaan kadar ALB pada setiap perlakuan.

Berdasarkan Gambar 1 terlihat bahwa kadar ALB nugget tempe kedelai dengan perbandingan brokoli mengalami peningkatan setelah disimpan selama 30 hari. Hal ini diduga karena proses hidrolisis terus berlanjut selama penyimpanan. Adanya air yang 
terkandung pada nugget tempe kedelai mempengaruhi reaksi hidrolisis (Rauf, 2015).Hasil penelitian pada Gambar 1 juga menunjukkan bahwa kadar ALB nugget tempe kedelai dengan perbandingan brokoli yang paling rendah setelah disimpan selama 30 hari yaitu pada perlakuan B sebesar 2,73\%. Namun pada perlakuan $\mathrm{C}$ dan $\mathrm{D}$ kadar ALB meningkat, bahkan lebih tinggi dari perlakuan A, dimana nugget tempe pada perlakuan A memiliki perbandingan brokoli $0 \%$ atau tanpa perbandingan brokoli. Kadar ALB yang naik turun atau fluktuatif diduga karena keberadaan antioksidan pada brokoli mampu memperlambat pembentukan asam lemak bebas. Menurut Azeliya (2013), brokoli mengandung beta karoten yang tinggi dan bersifat antioksidan.

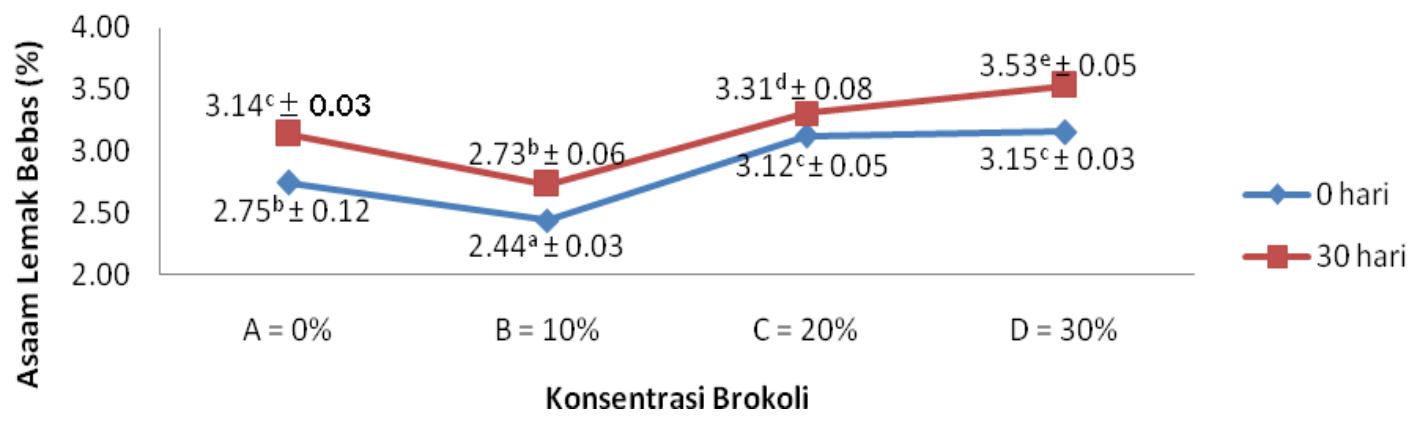

Gambar 1. Pengaruh Perbandingan Brokoli Terhadap Kadar Asam Lemak Bebas (ALB) Nugget Tempe

\section{Bilangan Peroksida}

Data bilangan peroksida nugget tempe kedelai dengan perbandingan brokoli pada berbagai konsentrasi ditunjukkan pada Gambar 2. Hasil penelitian menunjukkan bahwa bilangan peroksida nugget tempe kedelai dengan perbandingan brokoli pada berbagai konsentrasi di 0 hari berkisar antara 20,00 $\mathrm{meq} / \mathrm{kg}$ sampai $56,00 \mathrm{meq} / \mathrm{kg}$ sedangkan yang disimpan pada 30 hari berkisar antara 50,00 meq $/ \mathrm{kg}$ sampai 108,00 $\mathrm{meq} / \mathrm{kg}$. Berdasarkan hasil analisis sidik ragam 5\%, perlakuan perbandingan brokoli dalam nugget tempe memberikan pengaruh beda terhadap bilangan peroksida, yang berarti terdapat perbedaan bilangan peroksida pada setiap perlakuan.

Berdasarkan Gambar 2 terlihat bahwa bilangan peroksida nugget tempe dengan perbandingan brokoli mengalami peningkatan setelah disimpan selama 30 hari, diduga karena lemak yang terkandung pada nugget tempe kedelai itu sendiri dan dari margarin untuk proses pengukusan dapat mengalami reaksi oksidasi. Reaksi oksidasi mudah terjadi pada produk yang mengandung lemak (Hertanto, 2012).

Penghambatan oksidasi lemak pada nugget tempe optimal pada perlakuan B yaitu dengan perbandingan brokoli sebanyak 10\%. Hal ini diduga karena adanya kandungan antioksidan pada brokoli (Moreno, dkk, 2006; Sami dan Rahimah, 2015) yang dapat menghambat reaksi pembentukan senyawa peroksida pada nugget tempe. Namun perlakuan $\mathrm{C}$ dan $\mathrm{D}$ penghambatan oksidasi pada nugget tempe tidak optimal, justru bilangan peroksidanya lebih tinggi dari nugget tempe pada perlakuan A, dimana nugget tempe pada perlakuan A memiliki perbandingan brokoli $0 \%$ atau tanpa perbandingan brokoli. Hal ini dimungkinkan karena senyawa antioksidan telah bersifat prooksidan. Menurut Gordon (1990) dalam Kadji, dkk (2013) yang menyatakan bahwa besar konsentrasi antioksidan yang ditambahkan 
dapat berpengaruh pada laju oksidasi. Pada konsentrasi tinggi, aktivitas antioksidan grup fenolik hilang bahkan antioksidan tersebut menjadi prooksidan.

Naik turunnya bilangan peroksida pada produk nugget tempe dengan perbandingan brokoli diduga disebabkan karena laju pembentukan peroksida terjadi

lebih cepat dibandingkan kecepatan penguraiannya. Menurut Dewi, dkk (2011), angka yang lebih rendah bukan selalu berarti menunjukkan kondisi oksidasi yang masih berjalan pada tahap awal tapi dimungkinkan produk hasil oksidasi lemak sudah terurai menjadi senyawa lain pada tingkat lanjut

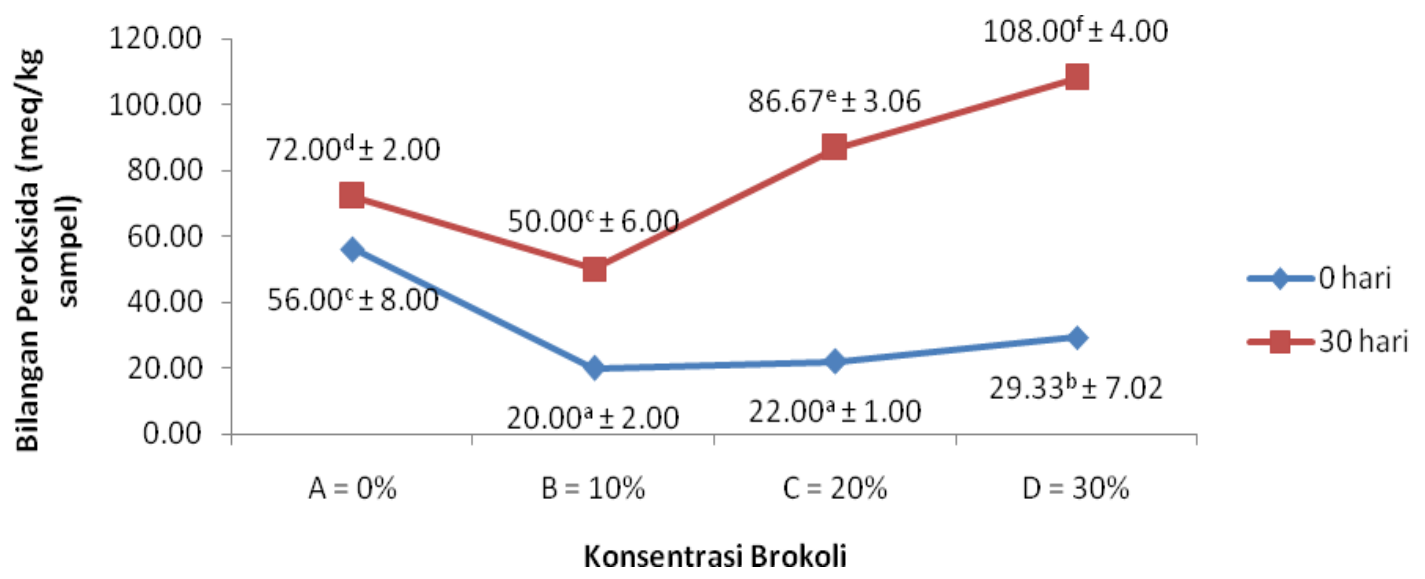

Gambar 2. Pengaruh Perbandingan Brokoli Terhadap Bilangan Peroksida Nugget Tempe

Penghambatan oksidasi lemak pada nugget tempe optimal pada perlakuan B yaitu dengan perbandingan brokoli sebanyak $10 \%$. Hal ini diduga karena adanya kandungan antioksidan pada brokoli (Moreno, dkk, 2006; Sami dan Rahimah, 2015) yang dapat menghambat reaksi pembentukan senyawa peroksida pada nugget tempe. Namun perlakuan C dan D penghambatan oksidasi pada nugget tempe tidak optimal, justru bilangan peroksidanya lebih tinggi dari nugget tempe pada perlakuan A, dimana nugget tempe pada perlakuan $\mathrm{A}$ memiliki perbandingan brokoli $0 \%$ atau tanpa perbandingan brokoli. Hal ini dimungkinkan karena senyawa antioksidan telah bersifat prooksidan. Menurut Gordon (1990) dalam Kadji, dkk (2013) yang menyatakan bahwa besar konsentrasi antioksidan yang ditambahkan dapat berpengaruh pada laju oksidasi. Pada konsentrasi tinggi, aktivitas antioksidan grup fenolik hilang bahkan antioksidan tersebut menjadi prooksidan. Naik turunnya bilangan peroksida pada produk nugget tempe dengan perbandingan brokoli diduga disebabkan karena laju pembentukan peroksida terjadi lebih cepat dibandingkan kecepatan penguraiannya. Menurut Dewi, dkk (2011), angka yang lebih rendah bukan selalu berarti menunjukkan kondisi oksidasi yang masih berjalan pada tahap awal tapi dimungkinkan produk hasil oksidasi lemak sudah terurai menjadi senyawa lain pada tingkat lanjut

\section{Nilai Thiobarbituric Acid (TBA)}

Data nilai TBA nugget tempe kedelai dengan perbandingan brokoli pada berbagai konsentrasi ditunjukkan pada Gambar 3. Hasil penelitian menunjukkan bahwa nilai TBA nugget tempe kedelai pada penyimpanan 0 hari berkisar antara $1,037 \mathrm{mg}$ malonaldehid/kg sampai 1,599 $\mathrm{mg}$ malonaldehid/g dan pada 
penyimpanan 30 hari berkisar antara 2,722 $\mathrm{mg}$ malonaldehid/kg sampai $6,113 \mathrm{mg}$ malonaldehid $/ \mathrm{kg}$. Berdasarkan hasil analisis sidik ragam $5 \%$, perlakuan perbandingan brokoli dalam nugget tempe memberikan pengaruh beda nyata terhadap nilai TBA.

Gambar 3 menunjukkan bahwa nilai TBA nugget tempe dengan perbandingan brokoli mengalami peningkatan setelah disimpan selama 30 hari. Hal ini diduga karena selama penyimpanan masih berjalannya reaksi oksidasi yang menghasilkan peroksida dan pada proses oksidasi lemak yang lebih lanjut salah satunya menghasilkan senyawa aldehid.

$$
\begin{array}{ll} 
& \text { Penghambatan oksidasi lemak } \\
\text { pada nugget tempe optimal pada }
\end{array}
$$

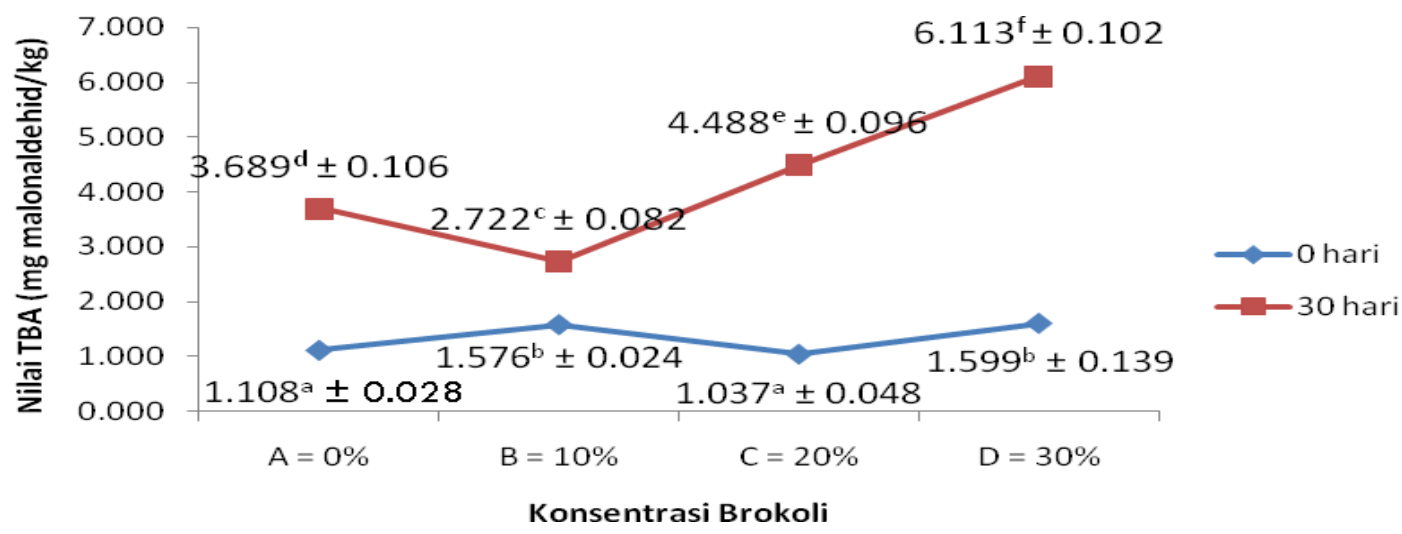

Gambar 3. Pengaruh Perbandingan Brokoli Terhadap Nilai TBA Nugget Tempe

Menurut Halimursyadah dan Murniati (2008), pemberian senyawa antioksidan yang tinggi dapat menyebabkan senyawa antioksidan berubah menjadi prooksidan. Perubahan nilai TBA pada nugget tempe yang fluktuatif diduga karena hidroperoksida telah terurai menjadi senyawa lain pada proses oksidasi lemak yang lebih lanjut dan kecepatan dekomposisi hidroperoksida menjadi malonaldehid (Dewi, dkk, 2011).

\section{Tingkat Penerimaan Terhadap Warna}

Hasil analisis tingkat penerimaan terhadap warna nugget tempe dengan perlakuan B yaitu perlakuan B yaitu dengan perlakuan perbandingan brokoli sebanyak $10 \%$. Hal ini diduga karena kandungan antioksidan pada brokoli (Azeliya, 2013) dapat menghambat pembentukan senyawa malonaldehid (Hidayati, dkk, 2017). Namun perlakuan C dan D penghambatan oksidasi pada nugget tempe tidak optimal, justru nilai TBA pada kedua perlakuan tersebut lebih tinggi dari nugget tempe pada perlakuan A, dimana nugget tempe pada perlakuan A memiliki perbandingan brokoli sebanyak $0 \%$ atau tanpa perbandingan brokoli. Hal ini diduga karena senyawa antioksidan pada nugget tempe dengan perbandingan brokoli telah bersifat prooksidan. 
dari produk ini dapat diterima oleh panelis. Setelah digoreng warna dari nugget ini berubah menjadi cokelat kekuningan dan untuk nugget tempe dengan perbandingan brokoli adalah cokelat kehijauan.

Semakin banyak perbandingan brokoli pada produk nugget tempe, warna cokelat semakin pekat. Hal ini diduga karena pada tahap penggorengan terjadi reaksi pencoklatan. Reaksi pencoklatan akibat penggorengan adalah salah satu reaksi pencokelatan non enzimatis (Muchtadi dan Sugiyono, 2013).

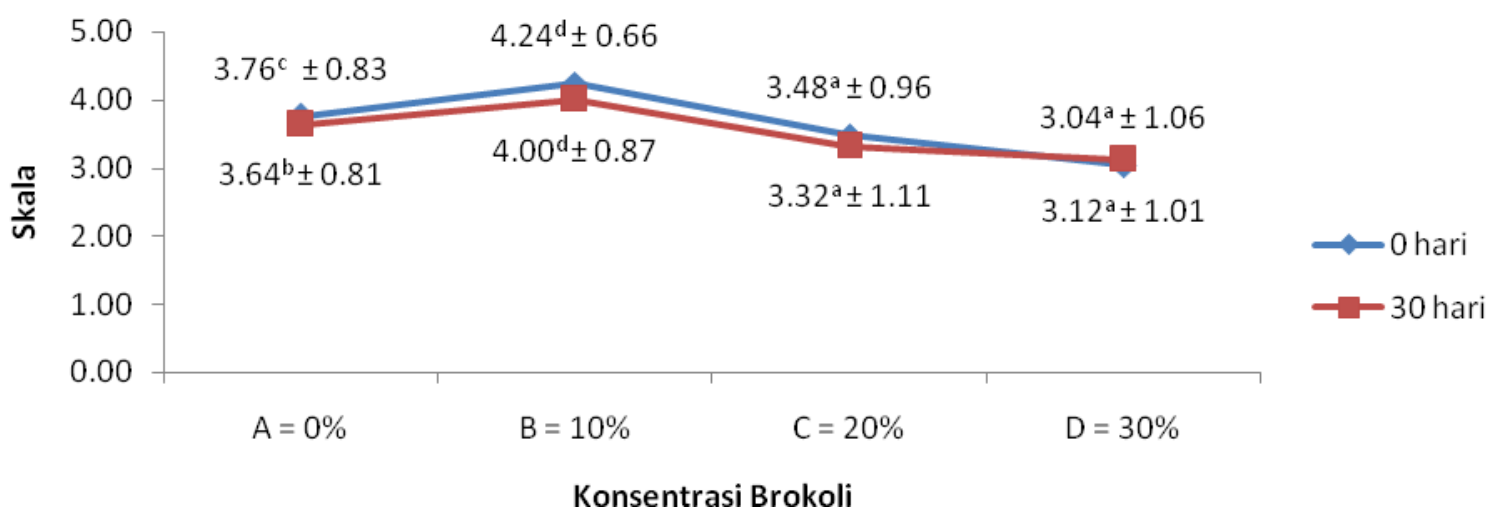

Gambar 4. Pengaruh Perbandingan Brokoli Terhadap Warna Nugget Tempe

Tingkat Penerimaan Terhadap Aroma

Data tingkat penerimaan terhadap aroma nugget tempe dengan perbandingan brokoli pada berbagai konsentrasi ditunjukkan pada Gambar 5. Hasil analisis tingkat penerimaan terhadap aroma nugget tempe dengan perbandingan brokoli pada penyimpanan 0 hari dan 30 hari diperoleh rata-rata 3,32 - 4,20. Berdasarkan hasil analisis sidik ragam 5\% untuk nugget tempe menunjukkan bahwa perlakuan memberikan pengaruh beda nyata terhadap aroma. Gambar 15 menunjukkan bahwa nilai tingkat penerimaan terhadap aroma nugget dengan rata-rata terendah diperoleh pada perlakuan D penyimpanan 0 hari yaitu 3,32 kategori netral dan ratarata tertinggi diperoleh pada perlakuan $\mathrm{A}$ penyimpanan 0 hari yaitu 4,20 kategori suka.

Hasil ini menunjukkan bahwa kesukaan panelis terhadap aroma produk rata-rata netral sampai suka yang berarti aroma dari nugget ini dapat diterima oleh panelis. Aroma pada nugget tempe disebabkan oleh adanya komponen volatil hasil degradasi komponen bahan pangan oleh panas dari tahap penggorengan sehingga menghasilkan aroma yang khas (Muchtadi dan Sugiyono, 2013). 


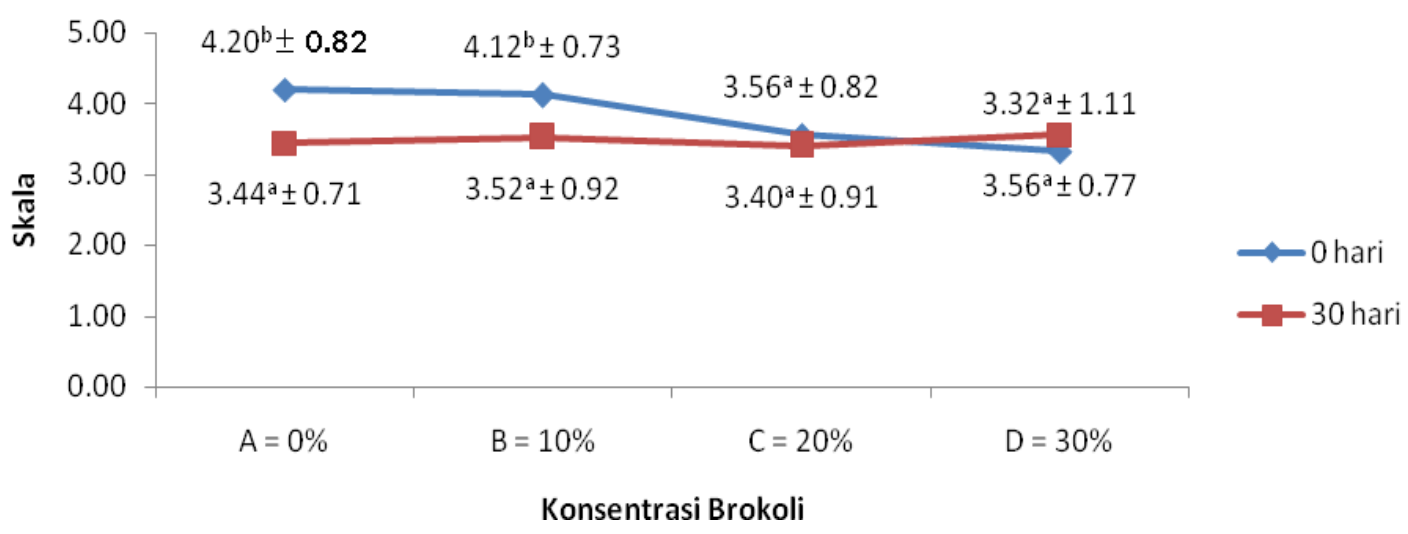

Gambar 5. Pengaruh Perbandingan Brokoli Terhadap Aroma Nugget Tempe

Tingkat Penerimaan Terhadap Rasa

Data tingkat penerimaan terhadap rasa nugget tempe dengan perbandingan brokoli pada berbagai konsentrasi ditunjukkan pada Gambar 6. Hasil analisis uji organoleptik terhadap rasa nugget tempe pada penyimpanan 0 hari dan 30 hari diperoleh rata-rata 3,20-3,68.

Gambar 6 menunjukkan bahwa nugget tempe dengan rata-rata terendah diperoleh pada perlakuan B penyimpanan
0 hari yaitu 3,20 kategori netral dan ratarata tertinggi diperoleh pada perlakuan $\mathrm{C}$ penyimpanan 0 hari yaitu 3,68 kategori suka. Hasil ini menunjukkan bahwa kesukaan panelis terhadap rasa produk rata-rata netral sampai suka yang berarti rasa dari nugget tempe dengan perbandingan brokoli dapat diterima oleh panelis.

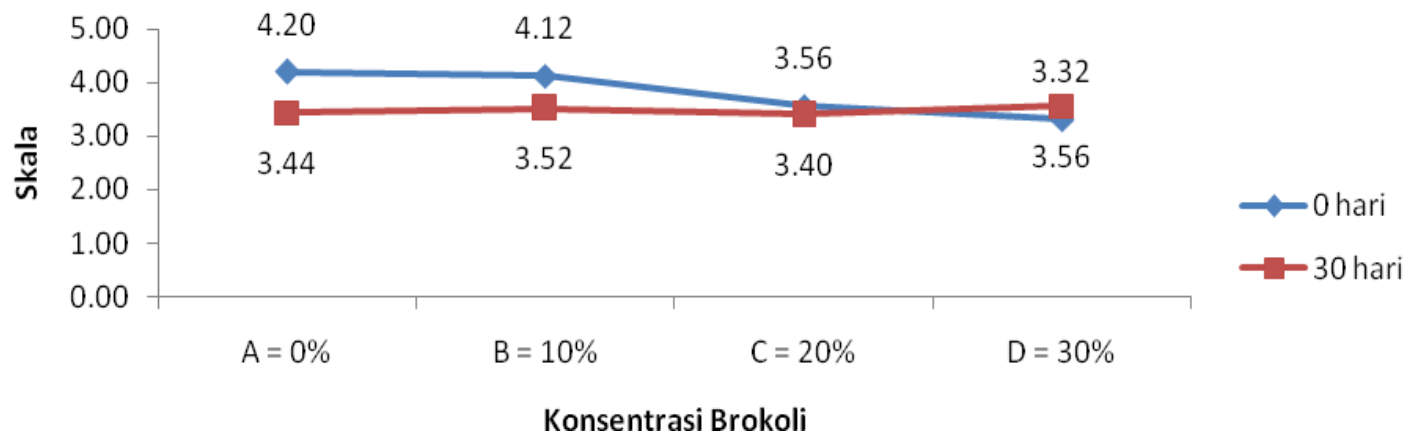

Gambar 6. Pengaruh Perbandingan Brokoli Terhadap Rasa Nugget Tempe

Berdasarkan hasil analisis sidik ragam $5 \%$ baik pada penyimpanan selama 0 hari dan penyimpanan selama 30 hari menunjukkan bahwa perbandingan brokoli pada produk nugget tempe tidak memberikan pengaruh terhadap rasa. Hal ini diduga karena komposisi bahan-bahan pembuat nugget seperti tepung tapioka dan bumbu-bumbu lainnya yang sama pada setiap perlakuan adonan nugget tempe.
Panelis mengatakan bahwa rasa dari setiap perlakuan tidak ada perbedaan yang mencolok Tahap penggorengan pada pembuatan nugget tempe mengakibatkan bahan pangan mengalami perubahan citarasa. Bahan pangan yang semula berasa mentah, akan terasa menjadi gurih dan lezat (Muchtadi dan Sugiyono, 2013). 
Tingkat Penerimaan Terhadap Tekstur

Data tingkat penerimaan terhadap tekstur nugget tempe dengan perbandingan brokoli pada berbagai konsentrasi ditunjukkan pada Gambar 7. Hasil analisis tingkat penerimaan terhadap tekstur nugget tempe pada penyimpanan 0 hari dan 30 hari diperoleh rata-rata 3,24 3,76 .

Gambar 7 menunjukkan bahwa nugget dengan rata-rata terendah diperoleh pada perlakuan D penyimpanan 30 hari yaitu 3,24 kategori netral dan ratarata tertinggi diperoleh pada perlakuan $\mathrm{C}$ penyimpanan 0 hari yaitu 3,76 kategorikan suka. Hasil ini menunjukkan bahwa kesukaan panelis terhadap tekstur produk rata-rata netral sampai suka yang berarti tekstur dari nugget tempe dengan perbandingan brokoli dapat diterima oleh panelis.
Berdasarkan hasil analisis sidik ragam baik pada penyimpanan selama 0 hari dan penyimpanan selama 30 hari menunjukkan bahwa perbandingan brokoli pada produk nugget tempe tidak memberikan pengaruh terhadap tekstur. Berdasarkan komentar dari panelis mengatakan bahwa tekstur pada semua perlakuan tidak ada perbedaan yang mencolok. Hal ini diduga karena komposisi bahan-bahan pembuat nugget seperti tepung tapioka dan bumbu-bumbu lainnya yang sama pada setiap perlakuan adonan nugget tempe. Tepung tapioka memiliki kadar amilosa sekitar 15,47 $24,01 \%$ dan kadar amilopektin sekitar $75,99-84,53 \%$ (Rahman, 2007). Kandungan amilopektin yang tinggi menghasilkan nugget yang semakin lekat dan kenyal (Winarno, 1991).

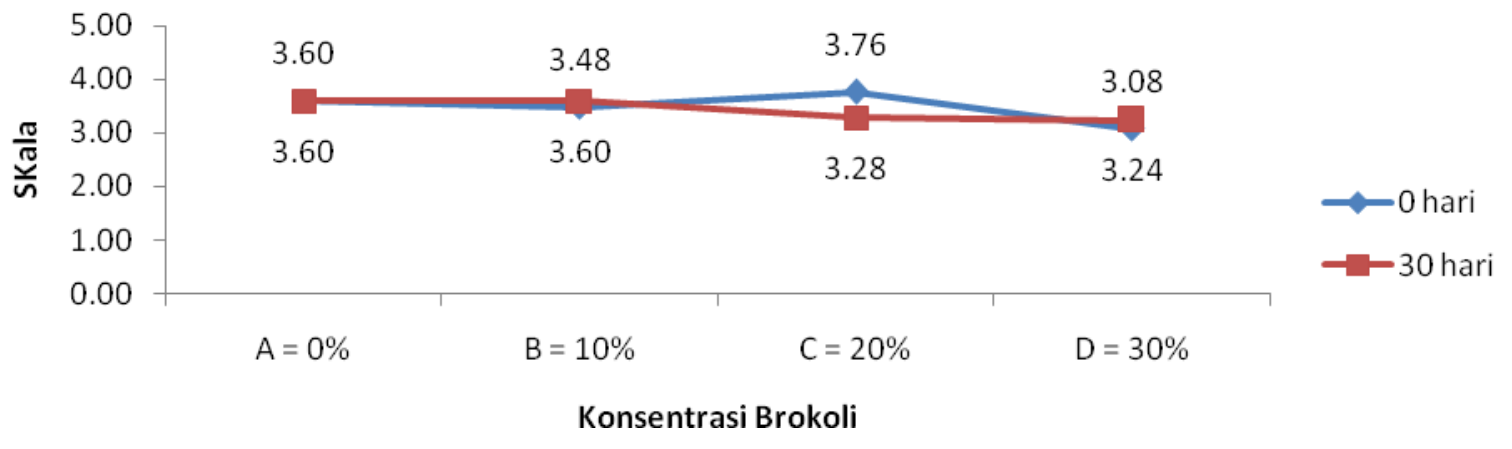

Gambar 7. Pengaruh Perbandingan Brokoli Terhadap Tekstur Nugget Tempe

\section{KESIMPULAN}

Konsentrasi brokoli dalam nugget tempe kedelai setelah penyimpanan selama 30 hari mempengaruhi penghambatan oksidasi lemak. Nugget tempe yang paling baik ditinjau dari kadar ALB, bilangan peroksida, dan nilai TBA adalah perlakuan $B$ yaitu dengan konsentrasi brokoli sebanyak $10 \%$. Tingkat penerimaan terhadap warna, aroma, rasa, dan tekstur dari nugget tempe kedelai oleh panelis berada pada kategori suka dengan konsentrasi brokoli sebanyak $10 \%$.

\section{DAFTAR PUSTAKA}

Alfiana, 2014. Karakterisasi Nugget Tempe Dengan Variasi Penambahan Jamur Merang dan Tiram. Skrispsi: Jurusan Teknologi Hasil Pertanian, Fakultas Teknologi Pertanian, Universitas Jember.

Amaliyah, Nurul. 2009. Perbedaan Kualitas Nugget Kacang Merah (Phaseoulus vulgaris) Sebagai Alternatif Makanan Untuk Vegetarian. Skripsi: Teknologi Jasa dan Produk, Fakultas Teknik, Universitas Negeri Semarang. 
Azeliya, Renny Maya. 2013. Pembuatan Bolu Brokoli (Brassica oleracea L) Dilihat dari Kadar Beta Karoten dan Kadar Vitamin C Serta Daya Terima. Naskah Publikasi: Program Studi Diploma III Gizi, Fakultas Ilmu Kesehatan, Universitas Muhammadiyah Surakarta.

Dewi, Eko N., Ratna I., Nuzulia Y. 2011. Daya Simpan Abon Ikan Nila Merah (Oreochromis niloticus Trewavas) Yang Diproses Dengan Metoda Penggorengan Berbeda. Jurnal Saintek Perikanan Vol. 6 no. 1, 2011:6-2. Fakultas Perikanan dan Ilmu Kelautan, Universitas Diponegoro. Semarang.

Halimursyadah, E. Murniati. 2008. Pengaruh Pemberian Senyawa Antioksidan Sebelum Simpan Terhadap Umur Simpan Benih Kapas (Gossypium hirsutum L.). J. Floratek 3: 1-9. Fakultas Pertanian Unsyiah, Nanggroe Aceh Darussalam.

Hertanto, B. 2012. Penggunaan Belimbing Wuluh untuk Menghambat Oksidasi dan Mempertahankan Mutu Organoleptik pada Dendeng Sapi Selama Penyimpanan. Skripsi: Fakultas Peternakan Institut Pertanian Bogor.

Hidayati, F., Y. S. Darmanto, Romadhon. 2017. Pengaruh Perbedaan Konsentrasi Ekstrak Sargassum sp. Dan Lama Penyimpanan Terhadap Oksidasi Lemak Pada Fillet Ikan Patin. Jurnal Saintek Perikanan Vol 12 No.12:116-123, Februari 2017. Universitas Diponegoro. Semarang.

Kadji, Miranty H., Max R.J. Runtuwene, Gayatri C. 2013. Uji Fitokimia dan Aktivitas Antioksidan dari Ekstrak Etanol Daun Soyogik (Sauraunia bracteosa DC). Jurnal Pharmacon, Vol. 2, No. 2, 2013. Program Studi Farmasi, FMIPA UNSRAT, Manado.
Luthfi, M., Yanti M. L., Yuliani A. 2017. Kajian Pembuatan Cookies dengan Penambahan Bubur Bayam Merah (Amaranthus gangeticus) dan Margarin sebagai Sumber Antioksidan. Jurnal Ilmiah Mahasiswa Pertanian Unsyiah, Vol. 2, No. 4, November 2017. Fakultas Pertanian, Universitas Syiah Kuala.

Moreno, D.A., M. Carvajal, C. LopezBerenguer. 2006. Chemical and biological characterization of neutraceutical compounds of broccoli. Journal of Pharmautical and Biomedical Analysis 41 (2006) 1508-1522. Dept. Ciencia y Tecnologia de Alimentos and Dept. Nutricion Vegetal, CBAS-CSIC, Murcia, Spain.

Muchtadi, T., R., Sugiyono. 2013. Prinsip Proses dan Teknologi Pangan. Penerbit: Alfabeta. Bandung.

Mulyani, S. 2013. Karakterisasi Tepung Tempe Dari Empat Varietas Kedelai Impor dan Implikasinya Menjadi Minuman. Skripsi: Fakultas Teknologi Pertanian, Institut Petanian Bogor.

Rahman, A. M. 2007. Mempelajari Karakteristik Kimia dan Fisik Tepung Tapioka dan Mocal (Modified Cassava Flour) Sebagai Penyalut Kacang Pada Produk Kacang Salut. Skripsi: Fakultas Teknologi Pertanian, Institut Pertanian Bogor.

Rauf, R. 2015. Kimia Pangan. Penerbit: Andi. Yogyakarta.

Rohaya, S., N. El Husna, K. Bariah. 2013. Pengaruh Bahan Pengisi Terhadap Mutu Nugget Vegetarian Berbahan Dasar Tahu dan Tempe. Jurnal Teknologi dan Industri Pertanian Indonesia Vol. (5) No. 1, 2013. Fakultas Pertanian, Universitas Syiah Kuala, Darussalam. Banda Aceh. 
Sami, Fitriyanti J., Sitti Rahimah. 2015. Uji Aktivitas Antioksidan Ekstrak Metanol Bunga Brokoli (Brassica oleracea L. var. Italica) Dengan Metode DPPH (2,2 diphenyl-1picrylhydrazyl) dan Metode ABTS (2,2 azinobis (3-etilbenzotiazolin)-6asam sulfonat). Jurnal Fitofarmaka Indonesia, Vol. 2, No. 2. Sekolah Tinggi Ilmu Farmasi Makassar.

Sudarmadji, Slamet., Bambang H., Suhardi. 1984. Prosedur Analisa Untuk Bahan Makanan dan Pertanian. Penerbit Liberty, Yogyakarta.

Taroreh, Mercy I.R. 1998. Pengaruh Intensitas Penggorengan Terhadap Tingkat Kerusakan Minyak Kelapa. Skripsi: Fakultas Pertanian, Universitas Sam Ratulangi. Manado.
Winarno, F. G. 1991. Kimia Pangan dan Gizi. Penerbit: PT Gramedia Pustaka Utama. Jakarta.

Yuliani, Fitri. 2012. Isolasi Senyawa Lutein Dari Ekstrak Bunga Brokoli Sebagai Antioksidan. Skripsi: Departemen Kimia, Fakultas Matematika dan Ilmu Pengetahuan, Institut Pertanian Bogor.

Zhang, Qing, A.S.M. Saleh, Jing Chen. 2012. Chemical alterations taken place during deep-fat frying based on certain reaction products: A review. Chemistry and Physics of Lipids 165 (2012) 662-681. China Agricultural University. China. 